\title{
The COVID-19 Pandemic and the Environment in the Asia Pacific
}

\author{
Hao Huang \\ Scripps College \\ USA \\ Email: hahuang [AT] scrippscollege.edu
}

\begin{abstract}
The COVID-19 pandemic has exposed the consequences of political and ecological choices that have been made and continue to be made in the Asia Pacific. Over recent decades, the region's rapid urbanization and industrialization have played a significant role in dynamic national economic development, a rapid rise in per capita income and the establishment of some of the world's fastest-growing cities. Development has, however, come at a heavy price: planetary-health experts believe that a byproduct of human intrusion into remote wilderness areas has been a sharp uptick in environmental degradation and zoonotic diseases such COVID-19. Moreover, people living with poor air quality are more susceptible to this virus, and airborne particulate matter may even help to spread the virus. A study conducted by the Harvard University T.H. Chan School of Public Health has confirmed that there is a statistical correlation between high levels of air pollution and increased Covid-19 mortality rates. [1]
\end{abstract}

The World Bank has stated that "COVID-19 has delivered a triple shock to the developing East Asia and Pacific $(E A P)$ region: the pandemic itself, the economic impact of containment measures, and reverberations from the global recession brought on by the crisis." [2] Certainly the COVID-19 pandemic has exposed the global sinews that bind the health of nations together. Vigilance directed at preventing cross-border COVID-19 contagion has led to increased awareness of cross-border pollution caused by carbon emissions from unregulated industrial production and transboundary haze from burning forests to accommodate agricultural expansion. Cross-border air pollution has led to strained relations between several Asia Pacific countries since it has long-term impact on the public health and welfare of national populations. To understand this predicament, it is important to examine diverse environmental histories and priorities that direct national environmental policies and implementation during this global pandemic.

\section{INITIAL COVID-19 ENVIRONMENTAL IMPACTS}

Disease ecologist Thomas Gillespie, an associate professor in Emory University's department of environmental sciences, studies how shrinking natural habitats are implicated in increasing the risk of transmitting diseases from animals to humans. Gillespie maintains that humans are responsible for producing conditions for zoonotic transmission by making "major landscape changes [that] are causing animals to lose habitats, which means species become crowded together and also come into greater contact with humans. Species that survive change are now moving and mixing with different animals and with humans." He continues, "I am not at all surprised about the coronavirus outbreak."[3]

In late September of 2020, the International Federation of Red Cross and Red Crescent Societies (IFRC) announced that the Asia Pacific was the region most affected by the "double whammy" of the coronavirus pandemic and natural disasters. The IFRC found that in 2020, eighty percent of the global total of people affected by COVID-19 as well as extreme climate events resided in the Asia Pacific, which it defines as encompassing 45 countries in South Asia, East Asia, Southeast Asia and the Pacific, but does not include Russia and the Americas. "These new figures confirm what we already knew from our dedicated volunteers on the frontlines: the climate crisis has not stopped for COVID-19, and millions of people have suffered from the two crises colliding," pronounced Francesco Rocca, president of the IFRC.[4]

The Ministry of Ecology and Environment of the People's Republic of China announced that during the COVID19 lockdown period of January - March 2020, concentrations of six major air pollutants during the early phase of the COVID-19 pandemic were significantly reduced. $\mathrm{NO}_{2}$ (one of a group of gases called nitrogen oxides that is an atmospheric pollutant produced by burning of fossil fuels) concentrations observed by the TROPOMI (TROPOspheric Monitoring Instrument) ${ }^{\mathrm{i}}$ on the European space Agency Copernicus Sentinel-5P satellite decreased about 35\% over China during the COVID-19 regulation period compared to the same period of 2019.[5] NASA and the European Space Agency satellite

\footnotetext{
i The TROPOMI instrument is a space-borne, nadir-viewing, imaging spectrometer combining a high spectral resolution with high spatial resolution $(3.5 \times 5.5 \mathrm{~km} 2$ at nadir for the $\mathrm{NO} 2$ observations), low noise, and a daily global coverage.
} 
measurements confirmed that $\mathrm{NO}_{2}$ (nitrogen dioxide) emissions in major Chinese cities in central and eastern China were down by 30 percent in the first two months of 2020. Lauri Myllyvirta, analyst at the Centre for Research on Energy and Clean Air who covers air quality and energy trends in China, states that "Taken together, the reductions in coal and crude oil use indicate a reduction in $\mathrm{CO}_{2}$ emissions of $25 \%$ or more [in 2020], compared with the same two-week period following the Chinese new year holiday in 2019.’[5]

This drop in air pollution in China during the initial phase of the COVID-19 lockdown in the first quarter of 2020 must be interpreted in the context of IQAir's pre-COVID mid-2019 national ranking of the PRC as $11^{\text {th }}$ in worst air quality in the world $\left(\mathrm{PM}_{2 .} .^{\mathrm{ii}}\right)$.[6] In March 2020, Marshall Burke, assistant professor at Stanford's Department of Earth System Science, proposed that the decrease in air pollution in China caused by the COVID-19 lockdown acted as a kind of public health measure:

\begin{abstract}
the reductions in air pollution in China caused by this economic disruption likely saved twenty times more lives in China than have currently been lost directly due to infection with the virus in that country. Using the He et al 2016 estimates of the impact of changes in $\mathrm{PM}^{\mathrm{iii}}$ [particulate matter] on mortality, I calculate that having 2 months of $10 \mathrm{ug} / \mathrm{m} 3$ reductions in $\mathrm{PM}_{2.5}$ likely has saved the lives of 4,000 kids under 5 and 73,000 adults over 70 in China. Using even more conservative estimates of $10 \%$ reduction in mortality per 10ug change, I estimate 1400 under-5 lives saved and 51700 over-70 lives saved. Even under these more conservative assumptions, the lives saved due to the pollution reductions are roughly 20x the number of lives that have been directly lost to the virus (based on March 8 estimates of 3100 Chinese COVID-19 deaths).[7]
\end{abstract}

Elsewhere in the Asia Pacific, a reduction in AOD (Aerosol Optical Depth, the measurement of the degree to which aerosols block the transmission of sunlight in the atmosphere) values obtained from Himawari- $8^{\text {iv }}$ was observed in Singapore, Malaysia, Brunei and the Philippines during the early phase of the COVID-19 pandemic in January-February 2020. Malaysia and Singapore's aggressive containment policies during the initial stage of the COVID-19 pandemic (Movement Control Order and "circuit breaker" measures) included border closures, prohibitions of mass gatherings, restrictions on religious activities and partial lockdowns enforced by the military. $\mathrm{NO}_{2}$ levels significantly dropped by $27 \%-34 \%$ in many cities in Southeast Asia.[8]

\title{
China
}

\section{SUBSEQUENT COVID-19 ENVIRONMENTAL DEVELOPMENTS}

Tropospheric $\mathrm{NO}_{2}$ column concentrations observed by the TROPOMI on the Sentinel-5P satellite confirmed that in March 2020, after the resumption of work and the gradual lifting of COVID-19 lockdown restrictions in the PRC, $\mathrm{NO}_{2}$ concentrations quickly increased to similar levels as in the previous year.[9] During the first two months of the COVID-19 pandemic lockdown, Zhejiang and Shanxi provinces reported NOx emission decreases - however, by March 12, 2020, measured levels of NOx had almost entirely rebounded. By April 2020, the level of PM 2.5 particles in a cubic meter of air over China was measured by NASA and ESA satellites at 33.93, a slight increase from 33.2 during the same month last year.[9] Several northern Chinese provinces have recently reported that NOx (a generic term for the nitrogen oxides identified with air pollution released as a gas into the atmosphere during the high-temperature combustion of fossil fuels) measurements have neared pre-COVID levels after resumption of industrial and commercial activities subsequent to the COVID-19 lockdown. Li Shuo, a climate and energy expert at Greenpeace China, has remarked "What is interesting is how rapidly the emissions have rebounded after the sharp fall seen in the first three months of the year...This may be an early sign that the positive trends seen during the epidemic period might be quickly reversed.’[10]

Data from the Center for Research on Energy and Clean Air (CREA) show concentrations of fine particles $\left(\mathrm{PM}_{2.5}\right)$ and nitrogen dioxide $\left(\mathrm{NO}_{2}\right)$ across China are now at the same levels as the previous year. Measurements taken by the United States National Oceanic and Atmospheric Association (NOAA) indicate that worldwide carbon dioxide $\left(\mathrm{CO}_{2}\right)$ levels have not experienced a permanent drop, but in fact have dramatically increased in just a few months after the initial COVID19 lockdown in early 2020. The average concentration of $\mathrm{CO}_{2}$ in the atmosphere in April 2020 was recorded as 416.21

\footnotetext{
ii $\mathrm{PM}_{2.5}$ refers to particulate matter with diameters of less than 2.5 micrometers (about $3 \%$ the diameter of a human hair) that are formed as a result of burning fuel and chemical reactions that take place in the atmosphere.

iii PM also refers to particle pollution, the sum of all solid and liquid particles suspended in air, many of which can be hazardous to the lungs and heart.

iv Himawari 8 (ひまわり8号) is the 8th of the Himawari geostationary weather satellites operated by the Japan Meteorological Agency
} 
parts per million (ppm), the highest since measurements began in Hawaii in 1958.[11] Globally, the drop in air pollution during the early phases of the COVID-19 pandemic appears to have been a short term phase.

China's National Development and Reform Commission (NDRC) announced in May 2020 that the PRC's finance ministry is boosting its environment protection budget to a total of 407.3 billion yuan ( $\$ 60$ billion) in 2020 , up from 390.6 billion yuan last year (\$57 billion).[12] To provide context, the USA EPA's enacted annual budget for 2020 was $\$ 9$ billion.[15] Recently, Beijing has announced that it is accelerating plans to invest $\$ 1.4$ trillion in seven areas of "new infrastructure," including carbon neutral high-speed rail and electric vehicle charging stations.

In the decade preceding the COVID pandemic, China became a global leader in wind and solar photovoltaic (PV) energy. In 2017, China's electricity generated by wind power reached 304.6 billion $\mathrm{kWh}$; as a result, China accounted for over a quarter of global wind-energy generation that year. In 2014, China became the world's largest producer of solar panels, and a year later it surpassed Germany's solar power generation capacity. China presently accounts for two-thirds of the world's solar-production capacity. In 2019, carbon neutral resources provided $26 \%$ of the PRC's electricity power (compared with $17 \%$ in the USA). China currently has the largest capacity of hydro, solar and wind power in the world.[13]

Japan

Japan is the seventh largest emitter of greenhouse gases (GHGs) in the world. It is promising that Japan's greenhouse gas emissions fell $2.7 \%$ to a record low in the 2019 financial year that ended in March 2020, that included the early stages of the COVID-19 pandemic and ensuing lockdown. Renewable energy sources including solar, wind, geothermal, hydro and biomass supplied $18 \%$ of electricity that year, growing from $9.5 \%$ of the electricity in 2010 . Despite this heartening news, environmental scholars suggest that Japan's present pace of reductions in emissions and waste is not sufficient to meet the goals of the 2030 Agenda for Sustainable Development: this includes the Paris Agreement, Sustainable Development Goals, and the Sendai Framework on Disaster Risk Reduction.

On January 27, 2020, Prime Minister Shinzo Abe designated COVID-19 as a "designated infectious disease" under the Infectious Diseases Control Law; it took nearly three months before the Japanese government categorized the 2020 coronavirus pandemic in Japan as a historical emergency situation on March 10, 2020. The Jibun Bank Japan Manufacturing Purchasing Managers' Index (PMI) fell to a seasonally adjusted 38.4 from 41.9 in April 2020, its lowest mark since the Great Global Recession of 2009. ${ }^{\vee}$ According to a survey conducted in June 2020, approximately 83 percent of business enterprises in the manufacturing industry stated that they already experienced an impact of the coronavirus (COVID-19) pandemic: an estimated total of thirteen thousand employees in the manufacturing industry were dismissed as a direct impact of business stagnation resulting from COVID-19 lockdown.[14] Japan suffered a record-breaking reduction in gross domestic product of almost $8 \%$ in the second quarter of 2020, the steepest decline recorded since modern records began to be kept in 1980 .

Given these dire economic circumstances, it comes as no surprise that the Dutch banking and finance group ING reports that in Japan there has been "virtually no concession to the environment in its COVID-19 stimulus projects and that only $0.02 \%$ of overall economic support has been earmarked for "green measures." [15] Although Minister Koizumi of the Japanese Ministry of the Environment has announced tighter restrictions on public financing for new overseas coal-fired power plants and the accelerated planned retirement of aging domestic coal generators, this has been offset by the Japanese government decision not to raise the GHG emission reduction target, as required under the Paris Agreement. At the end of March 2020, the Environment Ministry announced that it would neither raise nor revise the Nationally Determined Contribution (NDC, the numerical value of a country's commitment to reduce carbon emissions) from 2013 levels $26 \%$ by 2030. Critics of this apparent environmental policy backpedaling have conjectured that the COVID-19 recession persuaded the Japanese government to prioritize economic recovery over raising environmental standards.[16]

In 2020, headlines about the coronavirus pandemic overshadowed news about climate change in Japanese media. COVDI-19 concerns have dissuaded environmental activists from holding mass public demonstrations. The Japanese government has been preoccupied with responding to the ongoing pandemic's impact on public health and the national economy. Teruyuki Ohno, executive director of the Renewable Energy Institute and former director general of the Tokyo Metropolitan Government's Bureau of Environment, has reported that the Japanese national government has announced plans to construct 22 new coal-fired power plants across 17 sites over the next five years. Together the 22 power plants would emit 74.7 million metric tons of carbon dioxide each year, almost as much carbon dioxide annually as all the

v The 2009 Great Recession was a global economic downturn during which Global world product contracted outright for the first time. Precipitated by the financial crisis of 20072008, it was the worst economic crisis since the Great Depression of the 1930s. 
passenger cars sold each year in the United States. "2020 was supposed to be the last year to turn things around and begin the process of decarbonization," Ohno said. "If economic recovery and energy consumption in the wake of the pandemic goes in the wrong direction, that time will be lost along with any chance of achieving net zero carbon emissions by 2050. " [17]

\section{South Korea}

In 2019, South Korea ranked globally as 26th in countries with the worst air pollution, according to an IQAir report.[18] Yonhap news reports that in 2019, South Korea registered the worst $\mathrm{PM}_{2.5}$ level ${ }^{\mathrm{vi}}$ in air quality among the 35 wealthiest nations.[19] The ineffectiveness of past South Korean environmental protection policies is unequivocal. "Compared to other developed countries, our air quality is bad," says Park Rok-jin, a professor at Seoul National University's School of Earth and Environmental Sciences. Among member countries in the Organization for Economic Cooperation and Development, South Korea has the worst air quality.[20] South Korea's particulate pollution was twice the average for the 36 member countries in the Organization for Economic Co-operation and Development (OECD) in 2019.[21]

After the first confirmed case of COVID-19 occurred on January $20^{\text {th }}, 2020$, the Korean national government set its infectious disease alert level to yellow. It raised its alert to red after the number of COVID-19 cases surged, especially around Daegu in late February. Since March 2020, when social distancing due to COVID-19 began, $\mathrm{PM}_{2.5}$ and $\mathrm{PM}_{10}$ have been significantly reduced by $25.4 \%$ and $21.4 \%$ in Seoul and Daegu, respectively. In the springtime of 2020 (February 29 to April 19,) during the yellow dust season ${ }^{\mathrm{vii}}$, the $\mathrm{PM}_{10}$ and $\mathrm{PM}_{2.5}$ concentrations in 2020 during the social distancing period did not exceed the daily National Ambient Air Quality Standard (NAAQS) for the first time in decades. The improvement in air quality in April is a remarkable example of COVID-19 control measures' positive consequences on air quality[22]

South Korea's reliance on coal plants for power and diesel fuel for its vehicles has persisted through COVID-19 quarantine. On the other hand, there are indications that COVID-19 has begun to impact national environmental priorities. Despite economic reliance on "dirty" steel, automobile, and oil refinery industries, the South Korean government has inaugurated major policies to facilitate a "green turn" - an environmental transition. In July 2020, President Moon Jae-in launched the Korean New Deal. The US\$135 billion investment in green and digital technology features a Green New Deal that involves investing in advanced technology initiatives to create jobs. The plan features "smart grids" (digital technology that allows an energy utility to communicate with and respond to its customers and vice-versa), and creating microgrid communities that will make use of renewable energy and energy storage systems in regional areas, producing decentralized low-carbon energy systems. Circular economy initiatives will also be implemented such as reducing and recycling energy using advanced computerized power grids in factories.[23] The plan calls for an expansion of solar panels and wind turbines to 42.7 gigawatts in 2025, up from 12.7 gigawatts last year. The government will also install solar panels on 225,000 public buildings. Locally, South Korea's capital Seoul has initiated its own program of "green" remodeling of public buildings and housing in order to reduce emissions, of which seventy percent are produced by cooling and heating systems.[24]

\section{Vietnam}

In 2019, Vietnam ranked $15^{\text {th }}$ worst nationally in air pollution, according to an IQAir report.[25] Yale University's 2020 Environmental Performance Index ranked Vietnam $115^{\text {th }}$ out of 180 countries in air quality; Vietnam graded much lower than many of its Southeast Asian peers, including Singapore, Brunei, Malaysia and Thailand. The World Health Organization (WHO) found that over 60,000 deaths in Vietnam each year are linked to air pollution. Vietnam remains dependent on coal-fired power as its major source of electricity generation.[26]

By global standards, Vietnam has managed the COVID 19 crisis expertly. The number of infections and deaths has been minimal, with few community infections since September 2020. Despite strict social distancing measures and an unprecedented global recession, Vietnam will remain in positive growth territory, while the world economy is expected to contract by at least 4 percent. In East Asia, only two other countries - China and Myanmar - are expected to report positive GDP growth this year. Given the efficacy of its COVID-19 health policy response, Vietnam was well prepared to handle

\footnotetext{
${ }^{\text {vi }}$ Particulate matter (PM) in the air is a serious health threat in Korea as it contains nitrates, black carbon and mineral dust with aerodynamic diameters of less than 2.5 micrometers $(\mu \mathrm{m})$ that can be inhaled to penetrate the cardiovascular system.

vii The annual "yellow dust" spring storms originate in China's Gobi Desert, picking up heavy metals and carcinogens such as dioxin as it passes over Chinese industrial regions before sweeping south to envelop the Korean peninsula . It is responsible for scores of deaths and billions of dollars in damage every year in South Korea.
} 
the pandemic, leveraging its experience of dealing with previous viral threats, as its national health system performed above its peers. Its success in managing the COVDI-19 health crisis suggests that Vietnam is qualified to be a leader of the green recovery in the Asia Pacific, in the aftermath of the COVID-19 pandemic.

Vietnam has long borders with China; nonetheless, it managed to contain COVID-19 caused deaths to thirty-five people nationally. WHO's report, "From COVID-19 to Climate Change: How Vietnam can become the Champion of Green Recovery,'[27] questions why Vietnam has not been as effective in dealing with environmental and climate challenges as it has been with the COVID-19 crisis, given many parallels with the pandemic: environmental and climate disasters also harm large populations, cause widespread economic problems, and ultimately reveal the vulnerability of human welfare. Vietnamesel authorities have identified short-term measures: stricter regulations on new vehicle emission standards, better traffic control, enforcement of dust management measures for construction sites and transporting trucks, enhanced monitoring of industrial emissions and bans on charcoal stove use in cities. While these measures would ameliorate Vietnam's pollution crisis, sustained national environmental policies that match the comprehensiveness and strict implementation of national COVID-19 lockdown measures are long overdue.

\section{Indonesia}

A February 2021 IQAir report states that Indonesia has the sixth worst air quality among nations globally.[28] Indonesia is also the world's fourth largest greenhouse gas emitter, due to rapid deforestation, peatland megafires, and the burning of fossil fuels for energy. Air quality has been compromised by electricity generation from coal-fired plants and transport-related emissions. It is the largest energy user in South East Asia. Its rate of energy consumption growth is among the fastest in the world; electricity consumption per capita has more than doubled in the last decade. Indonesia is the world's biggest exporter of thermal coal and accounts for almost $90 \%$ of Southeast Asia's coal production. As of the first semester of 2019, all renewable energy sources accounted for $12.24 \%$ of power generation in Indonesia; greenhouse emitting sources such as coal, gas and oil accounted for the remaining $87+\% .[29]$

Indonesia was the only country in Southeast Asia to start construction of a new coal-fired power plant in the first six months of 2019, according to a report from Global Energy Monitor. The COVID-19 pandemic economic crisis has prompted Indonesia to earmark approximately IDR 720 trillion (USD 48 billion) to fund the national recovery. Although the national government has announced its intention to accelerate B30 biodiesel production, to diminish dependence on fossil fuel, the current National Economic Recovery (PEN) makes no attempt to set the country on a low-emissions pathway. A particular concern is that increased production of biofuel may result in expanding the area needed for palm oil plantations. The issue of forest clearance for palm oil has presented a major dilemma for Indonesia: between 2001 and 2018, Indonesia lost $16 \%$ of its tree cover, or nearly 26 million hectares of forest, according to a database kept by Global Forest Watch. The loss of those forests released the equivalent of about 10.5 gigatons of carbon dioxide emissions.[30]

Moreover, given shortages and distribution problems associated with the COVID lockdown, Indonesia plans to strengthen domestic food supply chains by creating food estates by converting areas formerly protected under the Peatland Development Project. Clearing land by slash and burn methods will worsen the Southeast Asian "haze season." Regional transboundary winds transport the haze throughout more than half of the ASEAN countries, including Singapore, Indonesia, Malaysia, Brunei, Thailand, and the Philippines. Increased short-term respiratory morbidity and mortality as a consequence of seasonal smoke exposure from episodic wildfires has become a regional public health concern.[31]

\section{Malaysia}

Malaysia is the third-largest consumer of energy in Southeast Asia. Petroleum, natural gas, and coal are the main energy sources, providing over $90 \%$ of energy consumed. The country is the 11th largest exporter of refined petroleum worth approximately $\$ 19.1$ billion annually. [32] In 2019, only $2 \%$ of Malaysia's energy was generated from renewable energy carbon neutral sources such as sunlight, wind, rain, tides, waves and geothermal heat. Over the past several decades, Malaysia's Department of Environment under the Ministry of Environment and Water has compiled a mixed record as an enforcer of environmental policy: government corruption and disorganization have led to an absence of effective mechanisms for ensuring compliance with environmental regulations.

The drop in Malaysia's oil income due to collapses of petroleum prices during the COVID-19 lockdown period has compelled both the federal and state governments to turn to other means of generating revenue. Economics professor Yeah Kim Leng from the Sunway University Business School has observed that "Increased logging of forests reserves and conversion of state land for oil palm and other agricultural crops will reduce the country's natural forest resource base as well as impact negatively other uses such as wildlife conservation, water catchments, biodiversity and environmental protection."'[33] Among several COVID-19 stimulus packages to rescue Malaysia's sagging economy are tax exemptions to incentivize car sales to revitalize the automotive industry (including those with internal combustion engines)l that may 
jeopardize serious efforts to reduce carbon emissions. COVID-19 has forced Malaysia to confront the dilemma that bedevils many countries in the Asia Pacific region -- a choice between prioritizing economic development or promoting public health.

These issues, if not properly addressed, have significant implications on sustainability of resources that businesses rely on for demand and supply of goods and services, as well as the environment and biodiversity. A hopeful sign came in May 2020 when the Malaysian Ministry of Energy and Natural Resources announced the fourth stage of its large-scale solar (LSS) program, designed to offer $1 \mathrm{GWac}$ worth of tender contracts and help reactivate Malaysia's economy in the wake of the global pandemic. The Ministry explicitly linked the fourth solar stage with the broader COVID-19 recovery efforts: it estimates that the $1 \mathrm{GWac}$ tender will involve 4 billion Malaysian ringgit (US\$927 million) in investment and create 12,000 new jobs.[34]

\section{RHETORIC OR ACTION?}

In anticipation of a post-COVID 19 global recession, Asian Pacific governments have earmarked vast sums of stimulus money towards reviving industrial output, consumption, employment and tourism. How will these post-COVID 19 economic recovery efforts impact the environment? At a virtual regional United Nations' gathering in Tokyo in late May 2020, Thai Prime Minister Prayuth Chan-ocha encouraged member states to "build back better," calling for a reset of national economies toward environmental and social sustainability. "The COVID-19 crisis has gravely impacted national and global economies," Prayuth told the United Nations Economic and Social Commission for Asia and the Pacific (ESCAP). "It will also affect our endeavors to achieve the sustainable development goals, or SDGs. But in every crisis lies an opportunity."[35]

The impact of greenhouse gas emissions in the Asia Pacific is clear: typhoons and floods of heavily populated low-lying coastal areas have become more intense and more frequent. More than 650 million people in the region are at risk to extreme climate events and rising sea levels caused by global warming. The Asian Pacific region's reliance on coal and oil fired power plants not only undermines national pledges to curtail noxious emissions and convert to green energy sources, it presents an existential choice for AP governments. Either risk giving up the dramatic rise in national living standards achieved through export-driven manufacturing economic growth or accept the increasing frequency of natural catastrophes arising from climate change that will impact national quality of life.

To complicate matters further, "green growth" planning faces two potentially irreconcilable objectives. While a circular economy that is based on eliminating waste and pollution, recycling products and materials, and regenerating natural systems lies at the core of green principles, green growth low-carbon technologies are expensive and highly material-intensive. For example, the International Energy Agency has determined that an electric car uses five times the quantity of minerals as a conventional car and that an onshore wind plant requires eight times the amount of minerals as a gas-fired plant of the same capacity.[36] In the COVID-19 era of reduced financial resources, how will Asia Pacific nations fund these high cost green initiatives? Furthermore, the vast land requirements for renewable energy facilities such as wind and solar plants may escalate the pressures that led to intrusion into wildlife habitat linked to transmission of zoonotic diseases such as COVID-19.

Asia Pacific nations' decisions to limit social, business and travel activities led to dramatic changes in regional air pollution levels during the early phases of the COVID-19 outbreak and roused awareness of the need for cross-border cooperation to improve air quality across the Asia Pacific region. Their success in managing the health crisis of the ongoing COVID-19 pandemic starkly contrasts with their failure to address global climate change by enacting effective environmental measures What have Asia Pacific governments learned from controlling the COVID-19 pandemic effectively, by combining government control, economic incentives and effective communication to ensure public compliance with a government agenda, whether it relates to a viral pandemic or environmental crisis? The choices are stark, but this does not have to become a zero sum game. The COVID-19 global pandemic crisis is shared by all, endured by all. Asia Pacific nations' choices on how to proceed will help determine the future of our global environment and species existence.

\section{REFERENCES}

[1] Wu Xiao, Nethery, R. C., Sabath, B. M., Braun, D., \& Dominici, F.. 'Exposure to air pollution and COVID-19 mortality in the United States', Science advances, 4 November 2020, 6:45 [online]. Available at https://pubmed.ncbi.nlm.nih.gov/33148655/ (Accessed 2 January 2021) 
[2] Lee Yen Nee. 'East Asia poverty could rise for first time in 20 years due to the pandemic, World Bank says', $C N B C$, Finding Solutions, 29 September 2020 [online]. Available at https://www.cnbc.com/2020/09/29/poverty-to-rise-in-eastasia-for-first-time-in-20-years-due-to-covid-world-bank.html (Accessed 4 December 2020)

[3] Vidal, John. 'Destroyed Habitat Creates the Perfect Conditions for Coronavirus to Emerge', Scientific American, 18 March 2020, 322:4 [online], Available at https://www.scientificamerican.com/article/destroyed-habitat-creates-theperfect-conditions-for-coronavirus-to-emerge/ (Accessed 29 August 2020)

[4] 'Asia Pacific hardest hit by COVID-19, climate-related disasters', Al Jazeera, News|Climate Change, 24 September 2020 [online]. Available at https://www.aljazeera.com/news/2020/9/24/asia-pacific-hardest-hit-by-covid-19-climaterelated-disasters (Accessed 2 December 2020)

[5] Myllyvirta, Lauri. 'Analysis: Coronavirus temporarily reduced China's CO2 emissions by a quarter', CarbonBrief, 19 February 2020, updated 30 March 2020 [online]. Available on https://www.carbonbrief.org/analysis-coronavirus-hastemporarily-reduced-chinas-co2-emissions-by-a-quarter (Accessed 12 January, 2021)

[6] 'World's most polluted countries 2019 (PM 2.5), IQAir, 7 February 2021, [online]. Available at https://www.iqair.com/world-most-polluted-countries (Accessed 7 February 2021)

[7] Burke, Marshall. 'Global Food, Environment and Economic Dynamics', G-FEED, 8 March 2020 [online]. Available at http://www.g-feed.com/2020/03/covid-19-reduces-economic-activity.html (Accessed 29 August 2020)

[8] Cheriyedath, Susha. 'COVID-19 lockdown measures reduced air pollution in Southeast Asia', NEWS Medical Life Sciences, 21 September 2020 [online]. Available at https://www.news-medical.net/news/20200921/COVID-19-lockdownmeasures-reduced-air-pollution-in-Southeast-Asia.aspx

(Accessed 6 February 2021)

[9] 'Coronavirus - China smog returns after pandemic cleared the air', PhysOrg | Environment, 8 May 2020 [online]. Available at https://phys.org/news/2020-05-china-smog-pandemic-air.html (Accessed 8 February 2021)

[10] 'China smog returns after pandemic cleared the air', France 24, 8 May 2020 [online]. Available at https://www.france24.com/en/20200508-china-smog-returns-after-pandemic-cleared-the-air (Accessed 10 February 2021)

[11] 'Record global carbon dioxide concentrations despite COVID-19 crisis', UN Environment programme, 11 May 2020 [online]. Available at https://www.unenvironment.org/news-and-stories/story/record-global-carbon-dioxideconcentrations-despite-covid-19-crisis (Accessed 10 February 2021)

[12] Reuters Staff. 'China to allocate $\$ 57$ billion to environment protection', Reuters, 21 May 2020 [online]. Available at https://www.reuters.com/article/us-china-environment-budget/china-to-allocate-57-billion-to-environment-protectionidUSKBN22Y0BU (Accessed 22 January 2021)

[13] 2019 electricity \& other energy statistics (preliminary),' China Energy Portal | 中国能源门户, 21 January 2020 [online]. Available at https://chinaenergyportal.org/2019-electricity-other-energy-statistics-preliminary/ (Accessed 22 January 2021)

[14] Statista Research Department. 'Coronavirus disease (COVID-19) in Japan - statistics \& facts,' statistaz; Health, Pharma \& Medtech State of Health, 27 November 2020 [online]. Available at https://www.statista.com/topics/6087/coronavirus-disease-covid-19-in-japan/ (Accessed 22 January 2021)

[15] Mikula-Wright, Rebecca. 'Japan must not forget climate change as it plans COVID-19 recovery', NIKKEI Asia, 2 September, 2020 [online]. Available at https://asia.nikkei.com/Opinion/Japan-must-not-forget-climate-change-as-it-plansCOVID-19-recovery (Accessed 2 January 2021)

[16] Chase-Lubitz, Jesse. 'COVID-19 a threat and opportunity for Japan's environmental activists', the japantimes, 16 April 2020 [online]. Available at https://www.japantimes.co.jp/news/2020/04/16/national/covid-19-environmentalactivists/ (Accessed 2 January 2021)

[17] Takahashi, Ryusei. 'Green recovery' offers Japan a chance to slash carbon emissions', japantimes $\mid$ Science \& Health [online]. Available at

https://www.japantimes.co.jp/news/2020/09/10/national/science-health/green-recovery-japan-decarbonize/

(Accessed 31 January 2021) 
[18] 'Air quality in South Korea', IQAir, 7 February 2021, [online]. Available at https://www.iqair.com/us/south-korea (Accessed 7 February 2021)

[19] 'South Korea - Country Commercial Guide: Air Pollution Control', International Trade Commission, 20 September 2020 [online]. Available at https://www.trade.gov/knowledge-product/korea-air-pollutioncontrol\#: : text=Yonhap\%20news\%20reports\%20that\%20in,year\%20by\%20approximately\%205.9\%20percent (Accessed 7 February 2021)

[20] Babe, Ann. 'High-flying Ideas?', U.S. News and World Report, 8 August, 2018, [online]. Available at https://www.usnews.com/news/world/articles/2018-08-08/seoul-turns-to-technology-to-battle-air-pollution

(Accessed 7 February 2021)

[21] 'South Korea Analysis: Air Pollution Cuts Lives Short by More Than A Year;, AQLI/Air Quality Life Index, 20 November 2019 [online]. Available at https://aqli.epic.uchicago.edu/news/south-korea-analysis-air-pollution-cuts-livesshort-by-more-than-a-year/ (Accessed 7 February 2021)

[22] Seo JH, Jeon HW, Sung UJ, Sohn J-R. 'Impact of the COVID-19 Outbreak on Air Quality in Korea', Atmosphere, 21 October 2020 11:10 [online]. Available at https://doi.org/10.3390/atmos11101137 (Accessed 7 February 2021)

[23] Kim, Sung-Young, Thurbon E., Tan Hao, Mathews J.. 'South Korea's Green New Deal shows the world what a smart economic recovery looks like', The CØNVERSATION, 9 September 2020 [online]. Available at https://theconversation.com/south-koreas-green-new-deal-shows-the-world-what-a-smart-economic-recovery-looks-like145032 (Accessed 7 February 2021)

[24] 'South Korea', IQAir Qualilty Index.[online]. Available at https://www.iqair.com/south-korea (Accessed 10 February 2021)

[25] 'World's most polluted countries 2019 (PM2.5)', IQAir World Air Qualilty Index.[online]. Available at https://www.iqair.com/us/world-most-polluted-countries (Accessed 10 February 2021)

[26] Nguyen, Sen. 'In Vietnam, air pollution a bigger daily threat than Covid-19, as smog envelops Hanoi', The Coronavirus Pandemic/This Week in Asia, 27 January 2021 [online]. Available at https://www.scmp.com/weekasia/health-environment/article/3119332/vietnam-air-pollution-bigger-daily-threat-covid-19 (Accessed 7 February 2021)

[27] 'From COVID-19 to Climate Change: How Vietnam can become the Champion of Green Recovery', World Bank Report Taking Stock, December 2020 [online]. Available at http://documents1.worldbank.org/curated/en/521421607981204344/pdf/Taking-Stock-From-COVID-19-to-ClimateChange-How-Vietnam-Can-Become-the-Champion-of-Green-Recovery.pdf (Accessed 10 February 2021)

[28] 'World's most polluted countries 2019 (PM 2.5)', IQAir

[29] 'Energy mix for power generation in Indonesia as of the first semester of 2019, by source', statista Energy \& Environment | Energy, 2021 [online]. Available at https://www.statista.com/statistics/993362/indonesia-energy-mix-forpower-generation-by-source/ (Accessed 23 January 2021)

[30] Schlanger, Zoë. 'The global demand for palm oil is driving the fires in Indonesia', QUARTZ, 18 September 2019 [online]. Available at https://qz.com/1711172/the-global-demand-for-palm-oil-is-driving-the-fires-in-indonesia/ (Accessed 13 January 2021)

[31] Cheong Kang Hao, Ngiam NJ, Morgan GG, Pek PP, Tan BY, Lai JW, Koh JM, Ong MEH, Ho AFW. 'Acute Health Impacts of the Southeast Asian Transboundary Haze Problem-A Review', International journal of environmental research and public health. 6 September 2019, 16:18 [online]. Available at https://pubmed.ncbi.nlm.nih.gov/31500215/ (Accessed 31 January 2021)

[32] Pines, Lawrence. 'Malaysia Commodity Trade: Learn Why Palm Oil Is A Volatile Export', commodity.com, 5 November 2020 [online]. Available at https://commodity.com/data/malaysia/

Accessed 10 February 2021) 
[33] Tan, Vincent. 'How will Malaysia's environment fare after the lifting of COVID-19 restrictions?' CNA channelnewsasia.com, 30 May 2020 [online]. Available at

https://www.channelnewsasia.com/news/asia/malaysia-environment-post-movement-control-order-budget-deficit-

12715506 (Accessed 31 January 2021)

[34] 'Beyond COVID: Malaysia's pandemic recovery plan and renewables records tumble in Europe', PV Tech, 5 June 2020 [online]. Available at https://www.pv-tech.org/beyond-covid-1-june-7-june/ (Accessed 7 February 2021)

[35] Regalado, Francesca. 'Asia risks missing 'green' economic reset after coronavirus', NIkkei Asia| ASIA INSIGHT, 23 June, 2020 [online]. Available at https://asia.nikkei.com/Spotlight/Asia-Insight/Asia-risks-missing-green-economic-resetafter-coronavirus (Accessed 3 December 2020)

[36] Sembiring, Margareth. 'The Same Old Normal for Climate Action in Post-Pandemic Southeast Asia', Emerging Voices on THE NEW NORMAL IN ASIA, 26 September 2020 [online]. Available at https://www.nbr.org/wpcontent/uploads/pdfs/publications/new-normal-emerging-voices-sembiring-092620.pdf (Accessed 2 January 2021) 